\title{
Practice of 2:1 waste rock dump reclamation slope at Batu Hijau - a 20 year journey creating the best legacy
}

\author{
M Maswahenu PT Amman Mineral Nusa Tenggara, Indonesia \\ SK Pujiastuti PT Amman Mineral Nusa Tenggara, Indonesia \\ G Pardede PT Amman Mineral Nusa Tenggara, Indonesia
}

\begin{abstract}
The Batu Hijau's orebody is a world-class copper-gold porphyry owned by PT Amman Mineral Nusa Tenggara located in previously uninhabited forestland with sloping terrain southwest of Sumbawa Island. The climatic condition is influenced by two distinct monsoon periods, namely the east monsoon which is characterized by low rainfall and humidity level and extends from May through September, and the west monsoon, which extends from November through March each year. Annual precipitation is 2,511 mm with over 75 percent of rainfall occurring during the west monsoon.

The construction phase started in 1997 and it took 3 years before production started in March 2000. Reclamation is performed concurrently and integrated into the annual mine plan update. Numerous studies had been performed since the early stages of exploration that including tree species selection, PROSPER forest vegetation/soil hydrology model to determine soil thickness, soil water holding capacity, and construction of 2:1 new test slope (NEWTS).

This paper outlines the development of a 2: 1 reclamation slope in the waste dump that has been carried out over 20 years from land preparation, erosion control techniques, tree transplanting, monitoring, and evaluation. This achievement assures that Batu Hijau reclamation program's goal to restore the ex-mining area to a forest similar to its pre-mining condition is achievable.
\end{abstract}

Keywords: concurrent reclamation, 2:1 reclamation slope, slope stability

\section{Site Description}

Batu Hijau is a large open cut copper-gold mine operated by PT Amman Mineral Nusa Tenggara (PTAMNT) located in the southwest of Sumbawa Island, Nusa Tenggara Province Indonesia. PTAMNT entered the operating period on 01 March 2000 following fulfillment of Contract of Work and Special Mining Business License for Production Operations with the Government of Indonesia.

Mining at Batu Hijau employs conventional open-pit mining methods including pre-stripping of soils and overburden, drilling and blasting of ore and waste rock, loading by electric shovel onto mine trucks, and hauling to low grade and medium grade stockpiles, primary crusher, waste dumps, or soil stockpiles. The current mine plan calls for ore extraction from the Batu Hijau open pit until 2029 and entering the mine closure period from 2030 to 2038. Over the course of the 25-year life-of-mine (LOM), a total of 1.387 billion ore-mill tons and 2.697 billion waste tons will be mined from the Batu Hijau open pit. 
Two major landforms will remain on the ex-mined area after mining. These include the Batu Hijau pit, East Dump, and Tongoloka Waste Rock Dump (WRD). Batu Hijau pit size would be 602.18 ha or 2,749 meters in diameter whilst East Dump and Tongoloka WRD would be 1,360.25 ha in total with natural properties that potentially acid-forming material in these landforms

\section{Concurrent Reclamation}

Reclamation and closure of the waste dump at Batu Hijau involve re-contouring, placement of a soil cover, and revegetation. The primary objectives of the waste dump reclamation and closure program are:

1. To limit contact of potentially acid-generating waste rock with meteoric water by covering with a thick layer of soil as soon as practicable.

2. To rapidly stabilize the ground surface and minimize erosion and sedimentation.

3. To provide some storage of precipitation within the cover for evapotranspiration and reduce infiltration rates into the waste dump.

4. To re-establish self-sustaining native vegetation, which will ultimately be similar in structure and diversity to that which existed before mining operations and meet approved final land use.

These goals would be established by placing subsoil and topsoil as a cover over permanently placed waste rock and establishing vegetation. Reclamation will be performed, to the extent practical, concurrently with pit and waste dump development and soil stockpile management. As of the end of 2020, the total waste dump already reclaimed was 323.39 ha out of 828.76 ha total disturbance for the waste dump.

\subsection{Baseline survey and Preliminary Reclamation studies}

The reclamation program for the Batu Hijau project began in approximately 1997, seven years before mining operation commenced with the initiation of baseline data collection, laboratory and nursery scale experiment and development of 2:1 test slope that focused on developing soil handling practices, erosion control methodologies, species selection, and slope stability as described below:

\subsubsection{Tree species trial}

Based on the soil baseline study conducted in 1999 (Golder Associates 1999) soils in Batu Hijau area relatively fertile in many aspects. Soil pH from 6-7 ensures the availability of many nutrients for plants. Total $\mathrm{N}$ appears relatively high $(>0.1 \%$ or $1000 \mathrm{ppm})$ in the upper $0.5 \mathrm{~m}$ of most soils with Carbon/Nitrogen $(\mathrm{C} / \mathrm{N})$ ratio of 10/1 suggest that Nitrogen $(N)$ is relatively mineable. Soil extractable Phosphorus $(P)$ is relatively low, averaging from 1.25 to $4.4 \mathrm{ppm}$. However, with the soil $\mathrm{pH}$ value relatively high, it may help ensure $\mathrm{P}$ availability to plant is relatively high.

Some soils in Batu Hijau pit area have a relatively high concentration of $\mathrm{Cu}$ are within the range of 900-2000 ppm that has been demonstrated to be toxic or inhibitory to some plants and soil microbe thus posed potential constraints on use as reclamation soil whilst average soil $\mathrm{Cu}$ worldwide in the soil is believed to be between 25 and 55 ppm (Thornton 1979 on Golder Associates, 1999). On the other hand, The Batu Hijau forest grew on soils exceeding $1,000 \mathrm{ppm}$. 
Nursery scaled tests have been carried out to evaluate the potential Cu toxicity. This trial concluded that due to the potential for $\mathrm{Cu}$ toxicity to some plants in soil biological process, with a mean concentration of $>500$ ppm total Cu for topsoil and $>900$ ppm for ppm was selected for use in reclamation.

\subsubsection{Soil thickness and water holding capacity}

The reclamation soil replacement program has been designed to provide a rooting medium that supplies soil nutrients and year-round soil moisture required by forest vegetation. In order to determine optimum reclamation soil thickness laboratory test and modelling was carried by means of the PROSPER model and field measurement of leaf area index (LAI) in several types of pristine forest around the mining site. Results showed that low soil permeability is favourable for the prevention of seepage into waste rock and for the retention of water within the reclamation soil profile, which supports dry season evapotranspiration, and that thickness of the soil of 2.75 meters formed a forest vegetation structure with LAI 5 which resembles the primary moist evergreen forest. Further research conducted by Juncosa (2014) concluded soil thickness of 2.25 meters, will form a forest vegetation structure with LAl similar that similar to deciduous forest.

\subsubsection{2:1 NEWTS}

A test slope with six contiguous panels with a 2:1 slope angle and $100 \mathrm{~m}$ slope length had been built in 2000 to demonstrate 2:1 reclamation slope can perform adequately at a reasonable cost and that the 2:1 slope will have adequate erosional and geotechnical stability to minimize the likelihood of exposing acid-generating materials (Figure 1).

Each panel was constructed by a different technique to form a soil cover that was approximately $3.00 \mathrm{~m}$ thick, comprising a $0.5 \mathrm{~m}$ thick topsoil layer and a 2.25 subsoil layer, with compaction methods included - some used a vibrating roller, others used track rolling, and some uses a combination of both, and different soil spreading methods - used downslope dozer movement and horizontal thin-lift.

The success criteria for the NEWTS trials are set out: (1) The ability of vegetation to take hold and thrive assessed by percentage ground and aerial cover, and species diversity; and (2) The stability of the slopes against criteria.

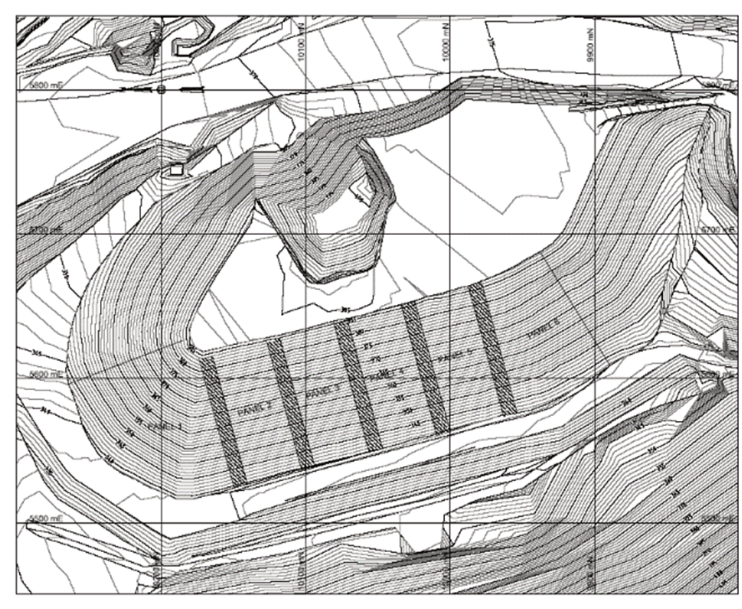

Figure 1 Plan view of the 2:1 NEWTS layout 
Several studies addressing geotechnical and plant rooting stability relating to slope stability were conducted during the study period that included: (1) bio-engineering studies to assess and quantify the various effects of vegetation and roots on slope stability;(2) geotechnical studies to assess material characteristics and the effects of soil strength, groundwater, soil suction and other factors on the stability of the test slopes.

After 3 years of monitoring performance (Golder et.al 2004 and Golder et.al 2005), several key conclusions had been made and summarized as follow:

1. The use of 2:1 slope rather than 3:1 slope for reclamation is likely to be preferable from the viewpoint of reducing surface erosion, particularly during the early stages when vegetation is being established. Field experience has demonstrated that $2 \mathrm{H}: 1 \mathrm{~V}$ slopes have superior erosion performance in comparison to $3 \mathrm{H}: 1 \mathrm{~V}$ slopes. In addition, the $2 \mathrm{H}: 1 \mathrm{~V}$ methodology produces environmental benefits such as reduced sediment generation due to less surface erosion, reduced surface water catchment area with less impact to water quality, less infiltration into waste dumps, and energy conservation through shorter haul distances requiring fewer haul trucks

2. $2 \mathrm{H}: 1 \mathrm{~V}$ slopes may result in increased runoff, which should result in less infiltration, reducing the amount of water available for acid production that eventually could cause a reduction in the amount of acid rock drainage generated.

3. The level of compaction has influenced the establishment of vegetation. Based on stability considerations and vegetation the subsoil should be well compacted to at least $95 \%$ of standard (Proctor) MDD or permeability does not exceed $5 \times 10-9 \mathrm{~m} / \mathrm{s}$. The level of compaction of the topsoil as low as $85 \%$ performed adequately in terms of slope stability and establishment of vegetation.

4. Revegetation methods have promoted the establishment of a climax plant community that will enhance soil strength through root development and that will increase water use promoting negative matric potentially or increased soil suctions.

5. Monitoring of several geotechnical instruments, show no deep-seated movements (according to inclinometer data) and show unsaturated slope (according to VWP data).

\subsection{Reclamation Design Criteria}

\subsubsection{Waste Dump Design}

The waste dump design criteria have been developed considering both the operational as well as closure issues pertinent to the safe construction of waste dump facilities (Table 1 and Figure 2). 
The waste dump design criteria are as follows:

Table 1 Final waste dump design criteria

\begin{tabular}{ll}
\hline Parameter & Criteria \\
\hline Dumping Face Angle & 37 degree (Repose Angle) - Stacking lowest lift first \\
Catch Bench Width & 22.5 meters \\
Lift Height & 45 meters \\
Ramp Width & 40 meters \\
Ramp Grade & $8 \%$ \\
Catch Bench Crossfall & $2 \%$ \\
Regraded Bench Face Angle & $2 \mathrm{H}: 1 \mathrm{~V}$ \\
Inter Ramp Angle & $2.5 \mathrm{H}: 1 \mathrm{~V}$ \\
Overall Slope Angle & $2.5 \mathrm{H}: 1 \mathrm{~V}$ or shallower \\
\hline
\end{tabular}

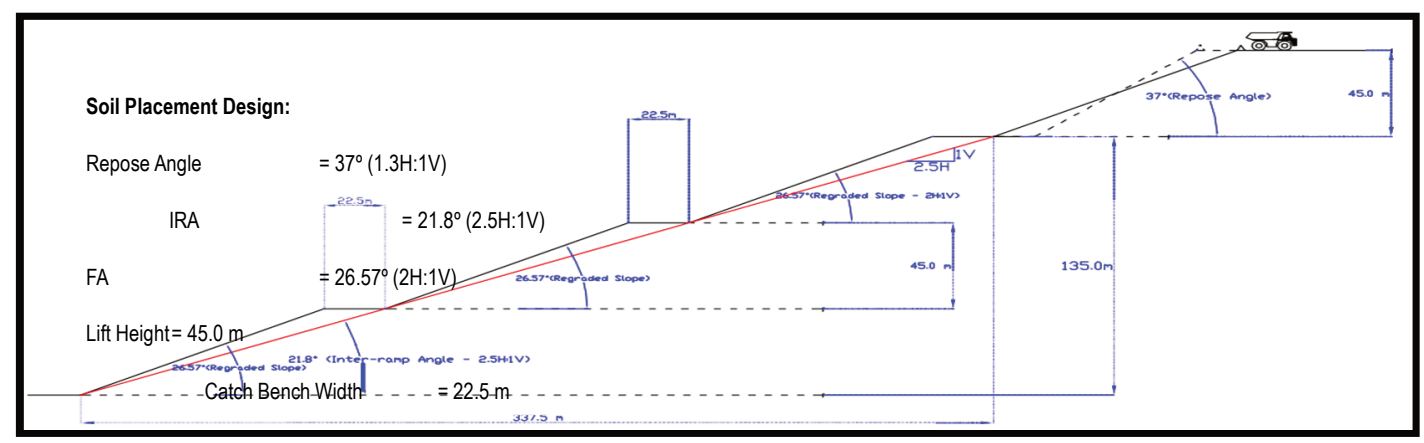

Figure 2 Final waste dump design criteria

\subsubsection{Subsoil and Topsoil Selection Criteria}

Reclamation involving subsoil and topsoil placement and revegetation is conducted concurrently with mining operations as final dump surfaces are completed. The reclamation procedure consists of the placement of a two-layered reclamation soil profile and stabilizing the reclaimed surface. Specific selection criteria for subsoil and topsoil, used in the waste dump reclamation program, have been developed by PT Amman Mineral Nusa Tenggara (Table 2). The subsoil consists of material, from the " $\mathrm{C}$ " horizon, and is typically light in colour when sandy or silty in texture (contains little clay) or reddish when clay-rich. Topsoil consists of material, from the dark brown " $\mathrm{A}$ " soil horizon and the reddish-brown " $\mathrm{B}$ " soil horizon, containing organic matter, and is typically clay-rich. In addition, subsoil and topsoil must comply with the selection criteria in Table 2 before it is placed on a reclamation slope. 
Table 2 Subsoil and topsoil selection criteria

\begin{tabular}{lll}
\hline Parameter & Subsoil & topsoil \\
\hline Total copper & $\leq 900 \mathrm{ppm}$ & $\leq 500 \mathrm{ppm}$ \\
Net carbonate value & $\geq-0.01 \%$ & $\geq-0.01 \%$ \\
$\mathrm{pH}$ & $>5$ & $>5$ \\
Percentage gravel & 5 to 35 & 0 to 25 \\
Percentage sand & 10 to 60 & 10 to 60 \\
Percentage fines & 30 to 75 & 30 to 85 \\
Plasticity index & 5 to 35 & 5 to 35 \\
\hline
\end{tabular}

\subsubsection{Subsoil and Topsoil Placement}

The spreading of subsoil on the $2 \mathrm{H}: 1 \mathrm{~V}$ slope is done in 0.5 -meter layers (prior to compaction) to a total compacted thickness of $2.25 \mathrm{~m}$, measured perpendicular to the slope. The number of subsoil layers placed is generally four (4) to five (5). The subsoil material is delivered at the crest of the lift that is being reclaimed. The dozer pushes the subsoil from the crest to the toe (from top to bottom). Any large logs, boulders, or other obstructions encountered during the spreading of soil layers are removed. Following each application of a $0.5 \mathrm{~m}$ sub-soil layer, compaction will be achieved by using a sheep-foot roller (Figure 3 ). The sheepsfoot roller leaves a roughened compacted surface that allows subsequent soil layers to be effectively "keyed in", increasing the overall soil profile strength.

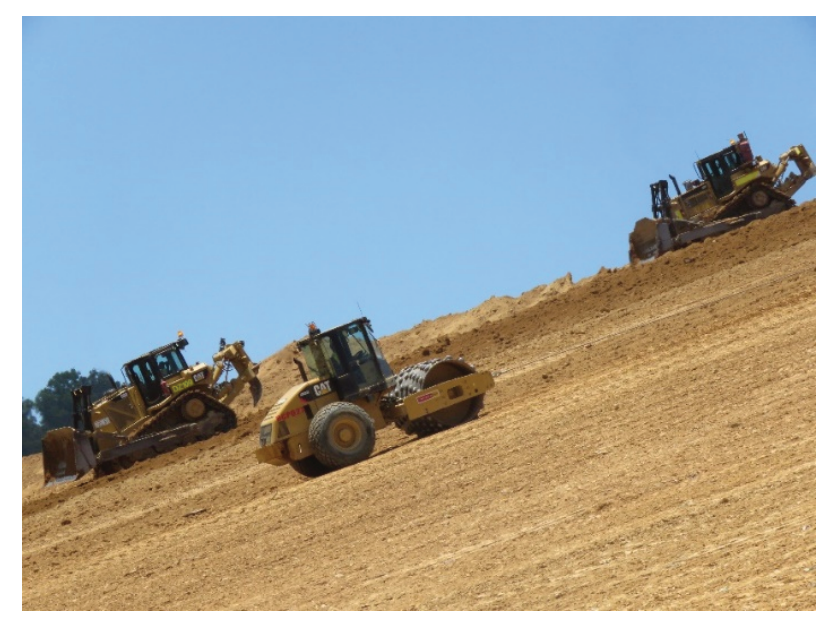

Figure 3 Soil compacting using sheepsfoot provides keyed in between layers 
Topsoil material is also delivered to the crest of the lift that is being reclaimed. Unlike the subsoil, topsoil placement occurs in one pass and at a single layer thickness of $0.5 \mathrm{~m}$. The placement process and criteria for subsoil and topsoil placement are summarized in Table 3 as follows:

Table 3 Subsoil and topsoil placement method

\begin{tabular}{|c|c|c|}
\hline Parameter & Subsoil & topsoil \\
\hline Placement & $\begin{array}{l}\text { end-tipped from the crest and } \\
\text { dozed down }\end{array}$ & $\begin{array}{l}\text { End-tipped from the crest } \\
\text { and dozed down }\end{array}$ \\
\hline $\begin{array}{l}\text { Compaction } \\
\text { method }\end{array}$ & sheepsfoot roller & track dozer \\
\hline $\begin{array}{l}\text { Degree of field } \\
\text { compaction }\end{array}$ & $\begin{array}{l}90 \% \text { passing } \geq 95 \% \text { of a standard } \\
\text { proctor }(0-250 \mathrm{~mm}) \\
90 \% \text { passing } \geq 90 \% \text { of standard } \\
\text { proctor }(250-500 \mathrm{~mm})\end{array}$ & $\begin{array}{l}90 \% \text { passing } \geq 85 \% \text { of } \\
\text { standard proctor }\end{array}$ \\
\hline $\begin{array}{l}\text { Moisture } \\
\text { content }\end{array}$ & -2 to $3 \%$ of optimum & -2 to $3 \%$ of optimum \\
\hline Total thickness & $\begin{array}{l}2.25 \mathrm{~m} \text { (perpendicular to the } \\
\text { slope) }\end{array}$ & $\begin{array}{l}0.5 \mathrm{~m} \text { (perpendicular to the } \\
\text { slope) }\end{array}$ \\
\hline Layer thickness & $0.5 \mathrm{~m}$ (4 to 5 layers) & $0.5 \mathrm{~m}$ (single layer) \\
\hline
\end{tabular}

Compaction should be carried out by ensuring that a minimum overlap of $0.3 \mathrm{~m}$ is achieved between successive passes of the compaction installation.

\subsubsection{Reclamation Quality Assurance/Quality Control (QA/QC)}

PTAMNT employs an effective QA/QC program to ensure that the $2 \mathrm{H}: 1 \mathrm{~V}$ reclamation slopes are constructed to the engineering and environmental criteria required. The following QA/QC program is implemented before, during, and after the construction of $2 \mathrm{H}: 1 \mathrm{~V}$ reclamation slopes:

- Soil Salvage

○ Field classification of soil at the point of salvage - CONTINUOUS

- Laboratory classification of chemical $(\mathrm{Cu} / \mathrm{NCV} / \mathrm{pH})$ and physical (grading \& Atterberg Limits) soil properties - ONCE PER DAY

- Field Compaction

- The soil characterization, compaction, and density testing as shown in Table 4 is performed as described.

The initial trial is at the beginning of a dry season reclamation construction period, testing will be undertaken to determine the number of passes required with the sheepsfoot roller to achieve the figure of $90 \%$ passing the required Degree of Field Compaction of the Subsoil. 
Table 4 Soil characterization, compaction, and density testing frequency

\begin{tabular}{lll}
\hline & Minimum test frequency \\
\cline { 2 - 3 } Test & $\begin{array}{l}\text { During the initial trial at } \\
\text { the start of each } \\
\text { construction Season }\end{array}$ & $\begin{array}{l}\text { During the remainder } \\
\text { of each construction } \\
\text { season }\end{array}$ \\
\hline $\begin{array}{l}\text { Field nuclear density test } \\
\text { from }\end{array}$ & 1 test per $500 \mathrm{~m} 3$ & 1 test per $1,500 \mathrm{~m} 3$ \\
0 to $0.25 \mathrm{~m}$ depth & & \\
$\begin{array}{l}\text { Field nuclear density test } \\
\text { from }\end{array}$ & 1 test per $500 \mathrm{~m} 3$ & 1 test per 20 field \\
0.25 to $0.5 \mathrm{~m}$ depth & density tests \\
$\begin{array}{l}\text { Field sand cone density } \\
\text { test from }\end{array}$ & $\begin{array}{l}1 \text { test per } 20 \text { field } \\
\text { density tests }\end{array}$ & $\begin{array}{l}1 \text { test per } 20 \text { field } \\
\text { to } 0.25 \mathrm{~m} \text { depth }\end{array}$ \\
$\begin{array}{l}\text { Laboratory compaction } \\
\text { curve }\end{array}$ & $\begin{array}{l}\text { Every field density test } \\
\text { Grading and Atterberg }\end{array}$ & $\begin{array}{l}1 \text { test per } 20 \text { field } \\
\text { density tests }\end{array}$ \\
limits tests & $\begin{array}{l}1 \text { test per } 20 \text { field } \\
\text { density tests }\end{array}$ & $\begin{array}{l}1 \text { test per } 20 \text { field } \\
\text { density tests }\end{array}$ \\
\hline
\end{tabular}

\subsubsection{Revegetation Practice}

The revegetation program employed by PAMNT consists of several phases including site preparation and installation of energy breaks hydroseeding and finally, a two-stage tree planting program. The program is intended to encourage natural succession and the species selected for revegetation are chosen to serve both long- and short-term purposes.

The objective of the initial phase is to physically stabilize the new landform with regard to erosion. The long-term objective relates more to ultimate land use, which in the case of the Batu Hijau waste dumps is re-establishing the primary moist evergreen forest canopy that was originally present in the pit and waste rock areas. Suitable vegetation for slope stabilization includes cover crops (grasses and legumes) and fast-growing fuel or forage trees. The advantage of such species (grasses such as Crotalaria, rice, Stylosanthes, trees such as Anthocephalus cadama, Paraserianthes falcataria) related to the relatively rapid rate at which substantial growth (hence slope stabilization) can occur. These species grow rapidly in the tropical environment and within one to two years, afford considerable benefits to dump stability through bioengineering.

Soil preparation before revegetation consists of the installation of row sprigging water energy breaks at 15-meter intervals, ijuk dispersion aprons, and jute netting (Figure 3).

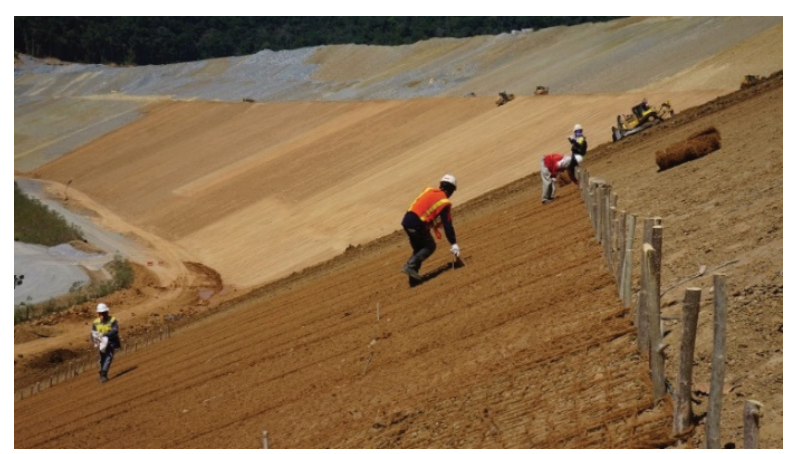

Figure 4 Coconet installation and row sprigging as energy breaker 
Following the completed installation of the energy breaks in the slopes, the entire slope surface will be hydroseeded, both for the protection of the soil and to enhance the anchorage of the applied revegetation treatment. A mixture of seeds, water, fertilizer, tackifier, dye, and mulch are then applied with a highpressure hose (hydroseeding) during the second phase of revegetation (Figure 4). The standard seed mixture currently used on the Batu Hijau waste dumps is listed in Table 5.

Table 5 Standard seed mix applicable for waste dump reclamation

\begin{tabular}{ll}
\hline Species & Application rate \\
\hline Oryza sativa (paddy) & $60 \mathrm{~kg} / \mathrm{ha}$ \\
Crotalaria sp (legume) & $6 \mathrm{~kg} / \mathrm{ha}$ \\
Stylosanthes hamata (Verano, Legume) & $1.2 \mathrm{~kg} / \mathrm{ha}$ \\
Sesbania grandiflora (legume) & $6 \mathrm{~kg} / \mathrm{ka}$ \\
\hline
\end{tabular}

Following completion of the hydroseeding, a two-phase tree transplanting process is conducted. Phase- 1 tree planting includes the transplanting of rapid growing species at a relatively high density to create an appropriate microclimate for subsequent " $\mathrm{A}$ " stratum (canopy) species. To accelerate this process tree seedlings are planted across the dump surfaces on 3,0 $\mathrm{m} \times 2 \mathrm{~m}$ centres over the reclaimed surface to produce a planted density of approximately 1,667 seedlings/ha (Figure 5).

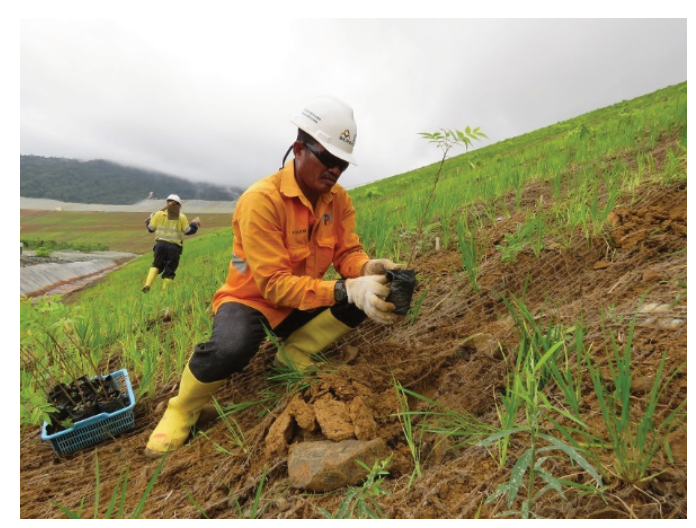

Figure 5 Transplanting of phase 1 native Tree Species

Phase-2 tree planting is conducted 1-2 years after Phase-1 has achieved a suitable density and microclimate for the native canopy species inter-planting. The phase 1 trees are thinned and trimmed as necessary to facilitate this process at a planting density of 555 seedlings/ha. Additional treatment of organic fertilizer and or compost can be applied to support soil nutrients for tree growing.

\subsection{Monitoring and evaluation}

\subsubsection{Geotechnical Stability}

Geotechnical monitoring reclamation slope at waste rock dump is aimed to determine the actual performance of waste dump stability and aiding risk minimization. The monitoring involving surface monitoring and subsurface monitoring with further subdivision into qualitative and quantitative systems. 
The qualitative system includes assessment of visual inspection and observation to detect instability as tension crack, slope bulging, and soil slump. Meanwhile, the quantitative system involves instruments measuring surface and subsurface, including displacement and groundwater monitoring.

Surface stability monitoring uses High Precision Global Positioning System (HPGPS) equipment for overall movement and vertical movement. Sixty-one instrumentations have been installed at final reclamation slope elevation 140 meters above sea level up to 450 meter above sea level.

Meanwhile, several subsurface monitoring equipment have been installed includes slope inclinometer, vibrating wire piezometer (VWP), and open standpipe and described below:

- 8 Slope inclinometers location for lateral displacement monitoring has been installed at reclamation slope at elevation $140 \mathrm{mRL}$ up to $345 \mathrm{mRL}$.

- 12 Vibrating Wire Piezometer (VWP) locations with total 33 sensor for groundwater pressure monitoring have been installed at elevation $140 \mathrm{mRL}$ up to $345 \mathrm{mRL}$. Twelve locations with total twenty-three sensors installed at reclamation slope at elevation $140 \mathrm{mRL}$ up to $345 \mathrm{mRL}$.

- 3 open standpipe locations for groundwater level monitoring have been installed at elevation 140 mRL.

Figure 6 and Figure 7 below show surface and subsurface monitoring locations at waste dump reclamation.

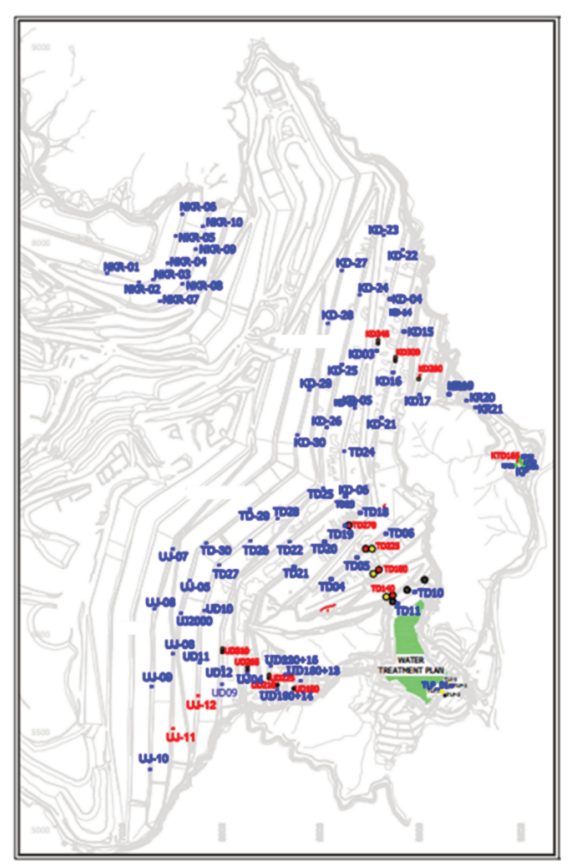

Figure 6 Typical monitoring system HPGPS, inclinometer, VWP, and OPS locations at reclamation slope 


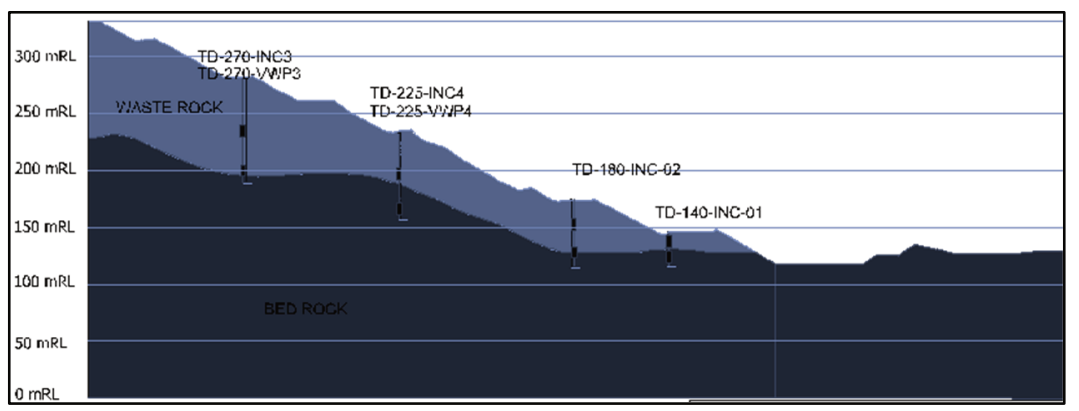

Figure 7 Typical subsurface monitoring; inclinometer and VWP sensor location at reclamation slope.

\subsubsection{Monitoring Result}

Geotechnical monitoring programs have been conducted and reported to the Government of Indonesia as required in the Environmental Impact Assessment (EIA) document. Monitoring records from HPGPS show that surface stability in the reclamation slopes being maintained and some movements are considered insignificant. The movements are only limited to the settlement of waste rock materials and do not appear to be of any direct response from previous significant rainfall events (Figure 8).

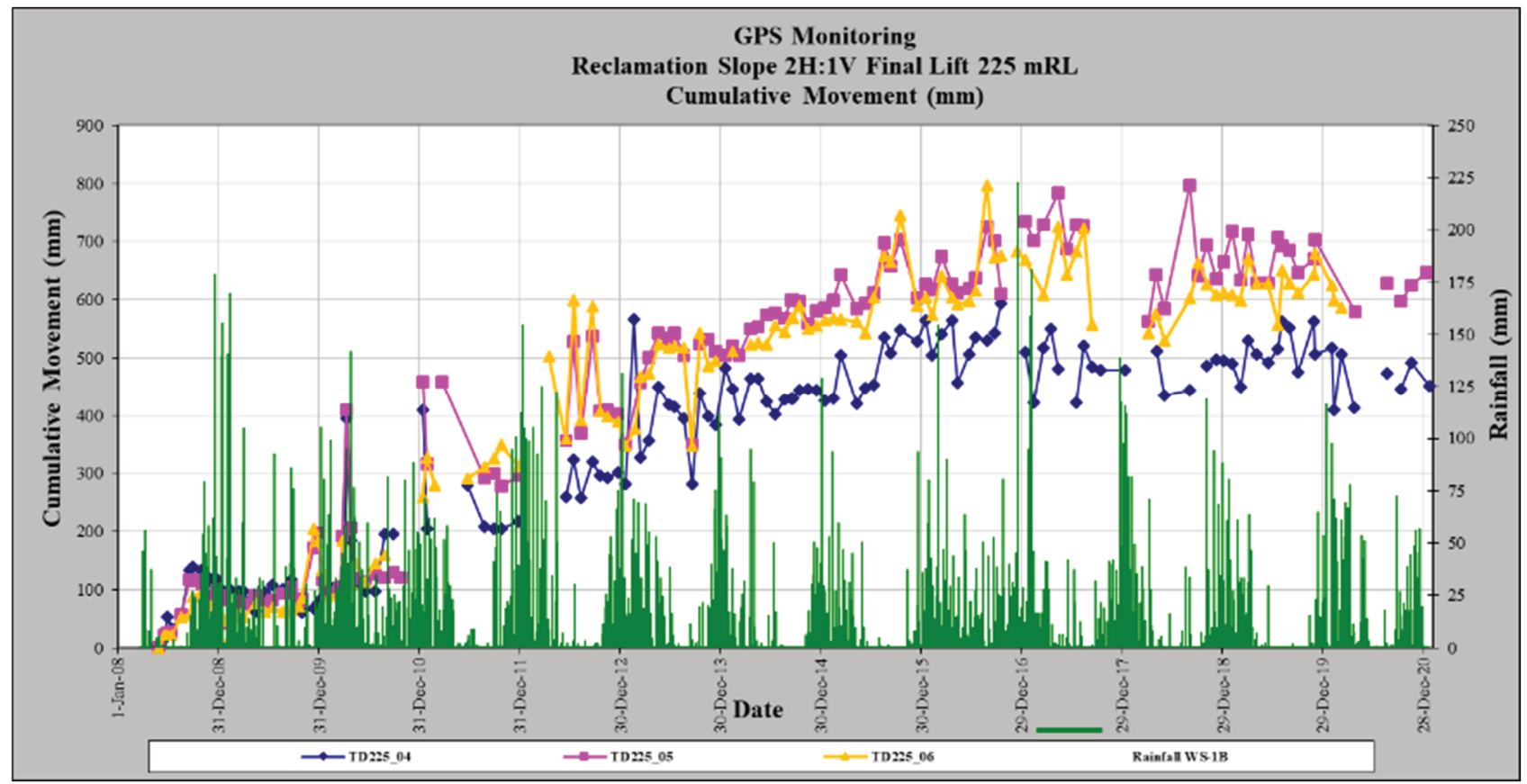

Figure 8 GPS Monitoring Cumulative Movement at Reclamation Slope Elevation 225mRL

The subsurface stability monitoring report is summarized below:

1. The slope inclinometer monitoring records show that the magnitude is a negligible and stable condition both for A-Axis reading and B-Axis readings. The movement does not appear to be of any direct response from previous significant rainfall events (Figure 9). 


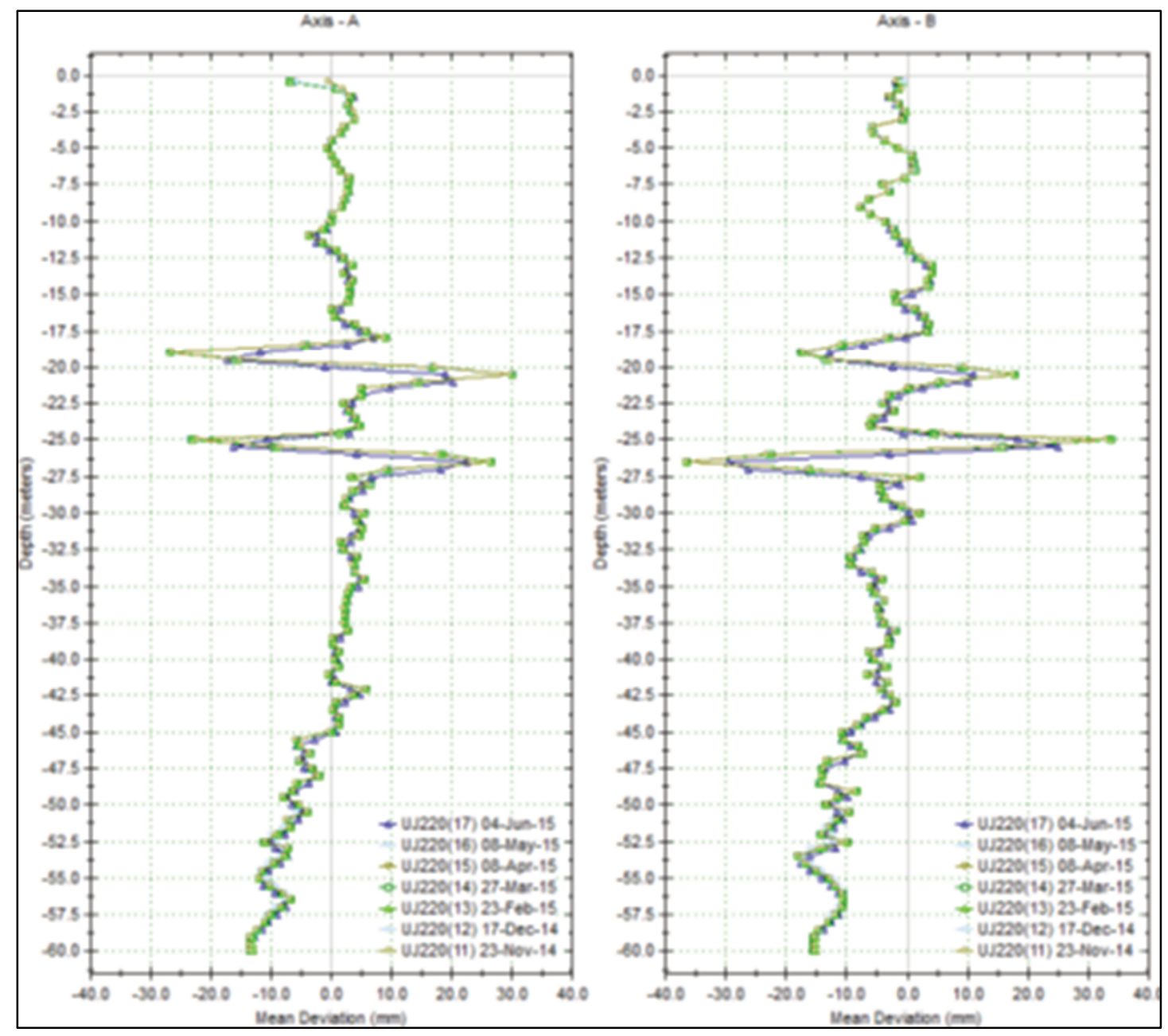

Figure 9 Inclinometer Monitoring Mean Deviation along Axis-A and Axis-B at Reclamation Elevation $220 \mathrm{mRL}$

2. The wire piezometer monitoring data recorded that small pore pressure occurred near the base of the dump and groundwater only rose marginally above the level of the sensor only on a few occasions following heavy rainfall events. The measurement has remained relatively static at the sensor level (Figure 10). 


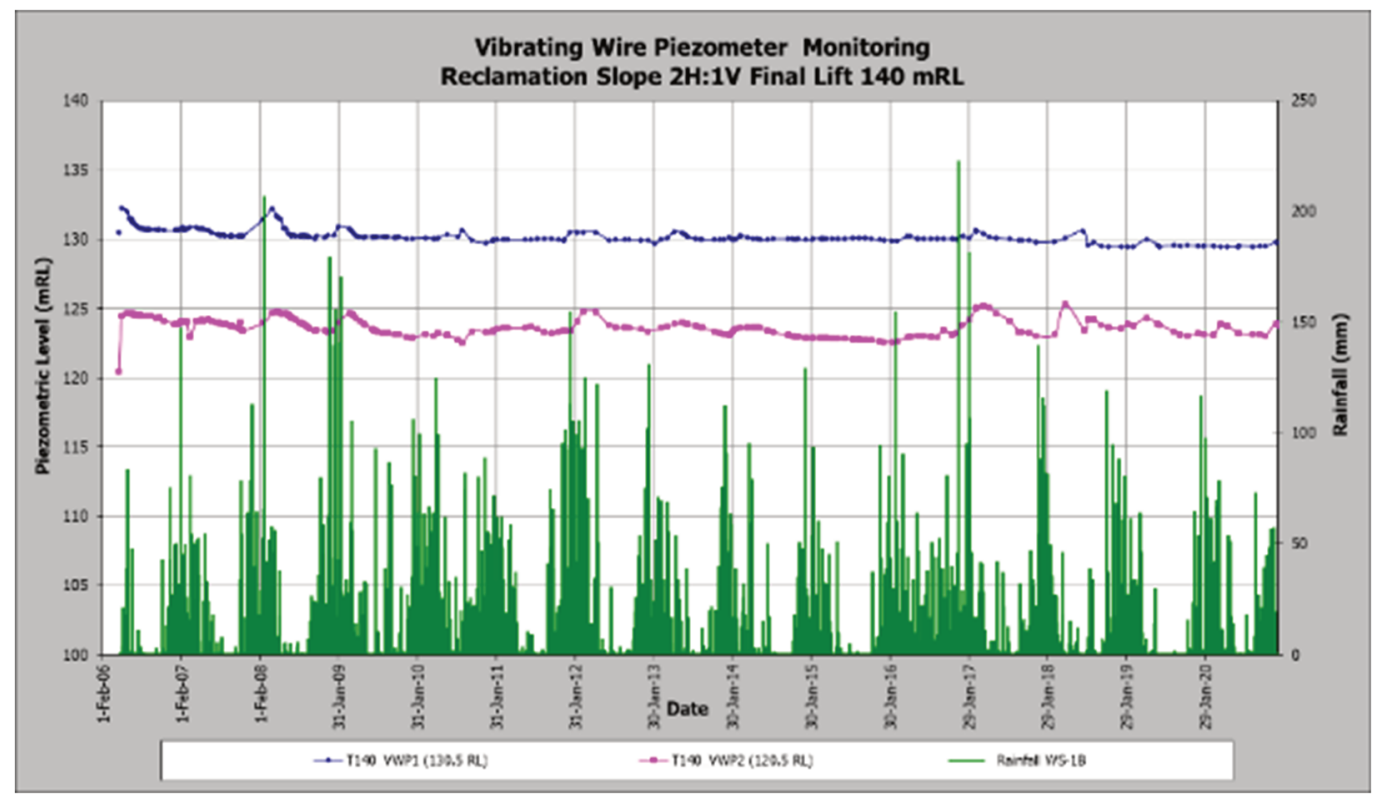

Figure 10 Vibrating Wire Piezometer Monitoring at Reclamation Elevation 140 mRL

3. The open standpipe monitoring data installed at the elevation level $140 \mathrm{mRL}$ indicates that groundwater levels are dependent on rainfall at the elevation levels of $122 \mathrm{mRL}$ to $127 \mathrm{mRL}$ (Figure 11).

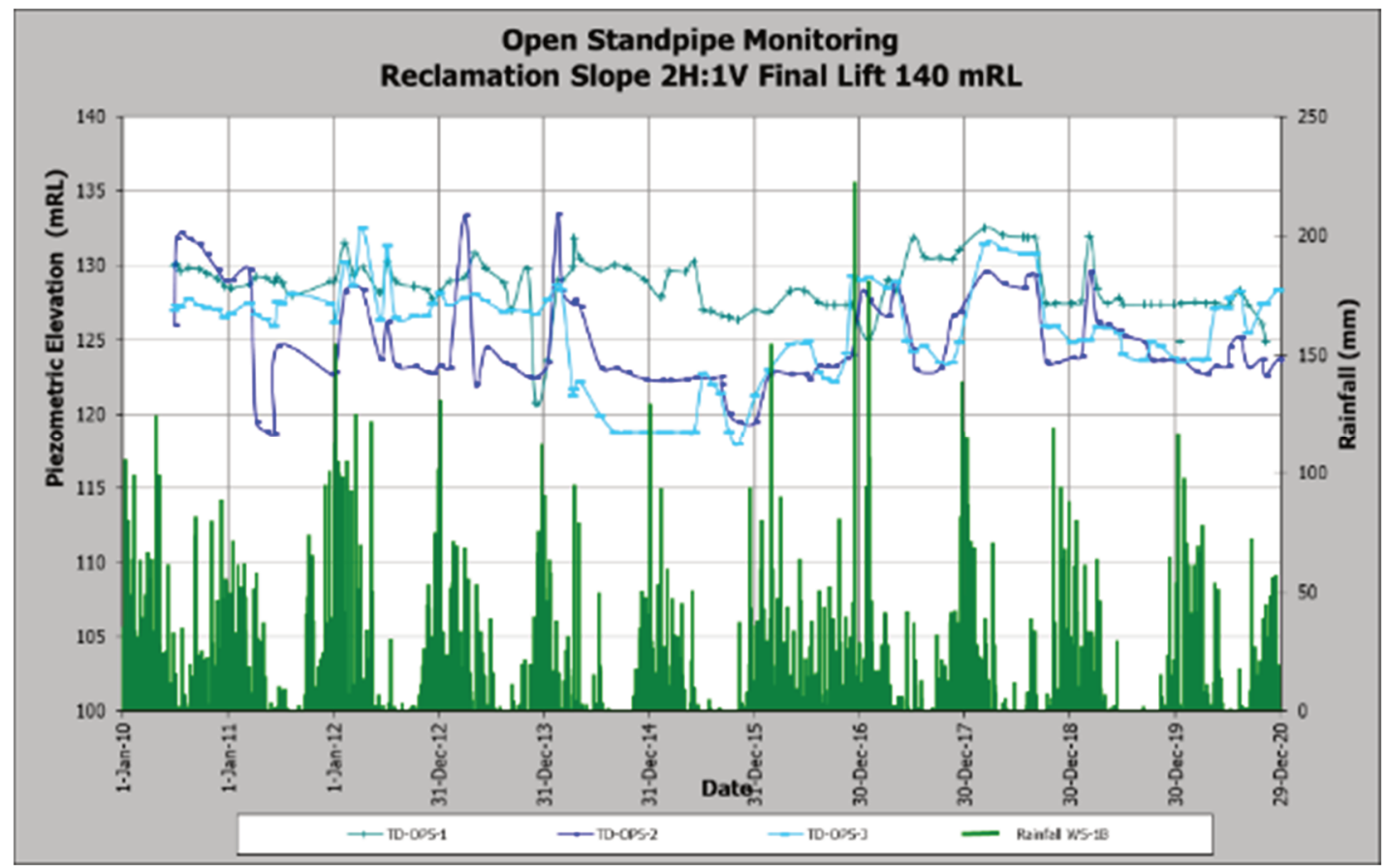

Figure 11 Open Standpipe Monitoring at Reclamation Elevation 140mRL

\subsubsection{Reclamation slope performance}

Failures at the reclamation slopes mostly occurred on 1-3 years old and categorized as shallow soil slumping and generally less than about $0.5 \mathrm{~m}$ in depth. These events are generally strongly correlated against the 
cumulative rainfall over the preceding three days caused a saturated topsoil layer leading to a reduction its strength (Golder Associates 2013).

All soil slumps that occurred have been surveyed and classified into the affected area and a calculated divot area. The affected area defined as the entire area within slumping, where debris accumulates, and lateral cracking is evident, and the divot area is defined as a slumped area in which the divot (negative topography) exceeds $250 \mathrm{~mm}$ in depth, measured perpendicular to the original slope. To date total affected soil slumps in the $2: 1$ waste dump reclamation slope was only $2.8 \%$.

Remediation is aimed to avoid soil slump propagation by backfilling and applied several bioengineering techniques such as installation of bamboo lattice retaining structures and plantings vetiver grass and trees (Figure 12).

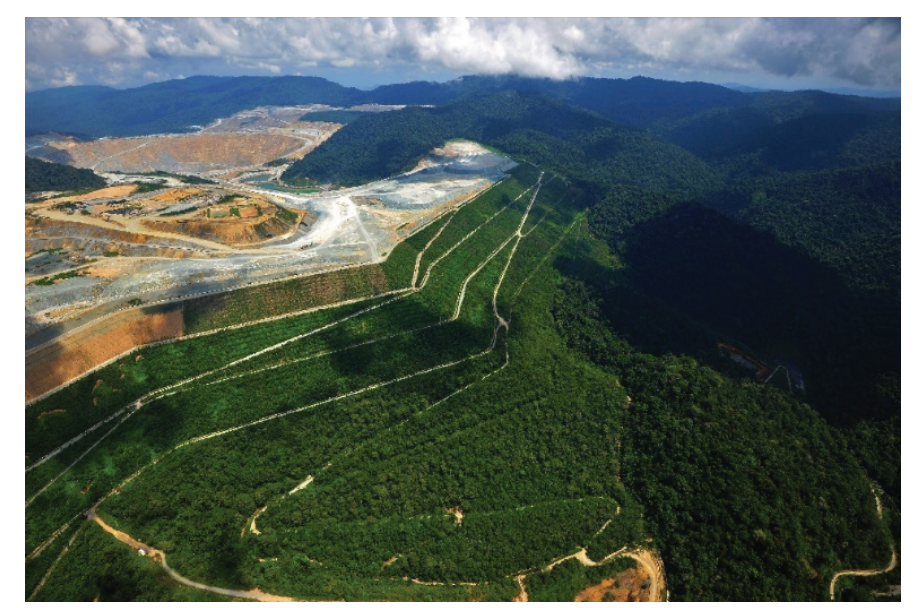

Figure 12 2:1 Tongoloka waste dump reclamation

\subsubsection{Flora}

\subsubsection{Diversity Indices}

Based on 2017 internal revegetation monitoring in Batu Hijau conducted by Pusat Studi Lingkungan Hidup IPB (2017) found that as reclamation areas are getting older by year, diversity index for sapling (small tree with height $>1.5 \mathrm{~m}$ and diameter at $<10 \mathrm{~cm}$ ), pole (timber tree with diameter $10-20 \mathrm{~cm}$ ) and tree (timber tree with diameter $>20 \mathrm{~cm}$ ) were also generally progressing toward the natural forest (Table 6).

\section{Table 6 Shannon diversity indices value $\left(\mathrm{H}^{\prime}\right)$}

\begin{tabular}{llll}
\hline Age (Yrs.) & Sapling & Pole & Trees \\
\hline 8 & 2.53 & 1.55 & 1.07 \\
6 & 2.08 & 0.81 & 0.19 \\
5 & 2.48 & 1.41 & 1.27 \\
4 & 2.75 & 1.54 & 0 \\
3 & 2.72 & 1.02 & 0 \\
2 & 2.38 & 0 & 0 \\
Natural Forest & 1.69 & 0.96 & 0.65 \\
\hline
\end{tabular}




\subsubsection{Evenness indices}

The $(E)$ evenness refers to how the species abundance are distributed among the species. When all species in a sample are equally abundant then an evenness index is maximum. Table 7 shows that besides rich in diversity, sapling, pole, and tree is distributed as evenly as natural forest.

Table 7 Evenness indices value (R)

\begin{tabular}{llll}
\hline Age (Yrs.) & Sapling & Pole & Trees \\
\hline 8 & 0.83 & 0.32 & 0.33 \\
6 & 0.73 & 0.45 & 0.28 \\
5 & 0.77 & 0.64 & 0.91 \\
4 & 0.79 & 0.67 & 0 \\
3 & 0.84 & 0.63 & 0 \\
2 & 0.86 & 0 & 0 \\
Natural Forest & 0.64 & 0.49 & 0.34 \\
\hline
\end{tabular}

\subsubsection{Richness indices}

The richness index is a count of the number of different species in a given area. As shown in Table 8 below, the richness index for sapling and pole at more than 3 years old for the reclamation area is generally similar to natural forest. However, the richness index for trees takes longer to get similar to natural forests.

Table 8 Richness indices value (R)

\begin{tabular}{llll}
\hline Age (Yrs.) & Sapling & Pole & Tree \\
\hline 8 & 3.84 & 2.68 & 1.23 \\
6 & 2.62 & 1.02 & 0.33 \\
5 & 3.64 & 1.67 & 1.11 \\
4 & 4.26 & 2.05 & 0 \\
3 & 3.34 & 1.19 & 0 \\
2 & 2.03 & 0 & 0 \\
Natural Forest & 3.09 & 1.86 & 2.34 \\
\hline
\end{tabular}

\subsubsection{Avifauna}

A recent report (PT Amman Mineral Nusa Tenggara 2021) in Figure 13 shows a time series of several birds found in the reclamation area of Tongoloka Dump (T Dump) and East Dump (E Dump), and in the control area of Nangka, Kanyolo, and Singa. From the graph, the number of bird species in the control area is still higher comparing to the reclamation area. The latest monitoring result in October 2020 described the number of tree species in all 3 natural forests vary between 30 until 35 species and between $19-21$ species in reclamation area. The abundance and diversity of birds are mostly seasonal. An increase is generally observed in April and a decrease in October, with a correlation with the food availability in nature. 


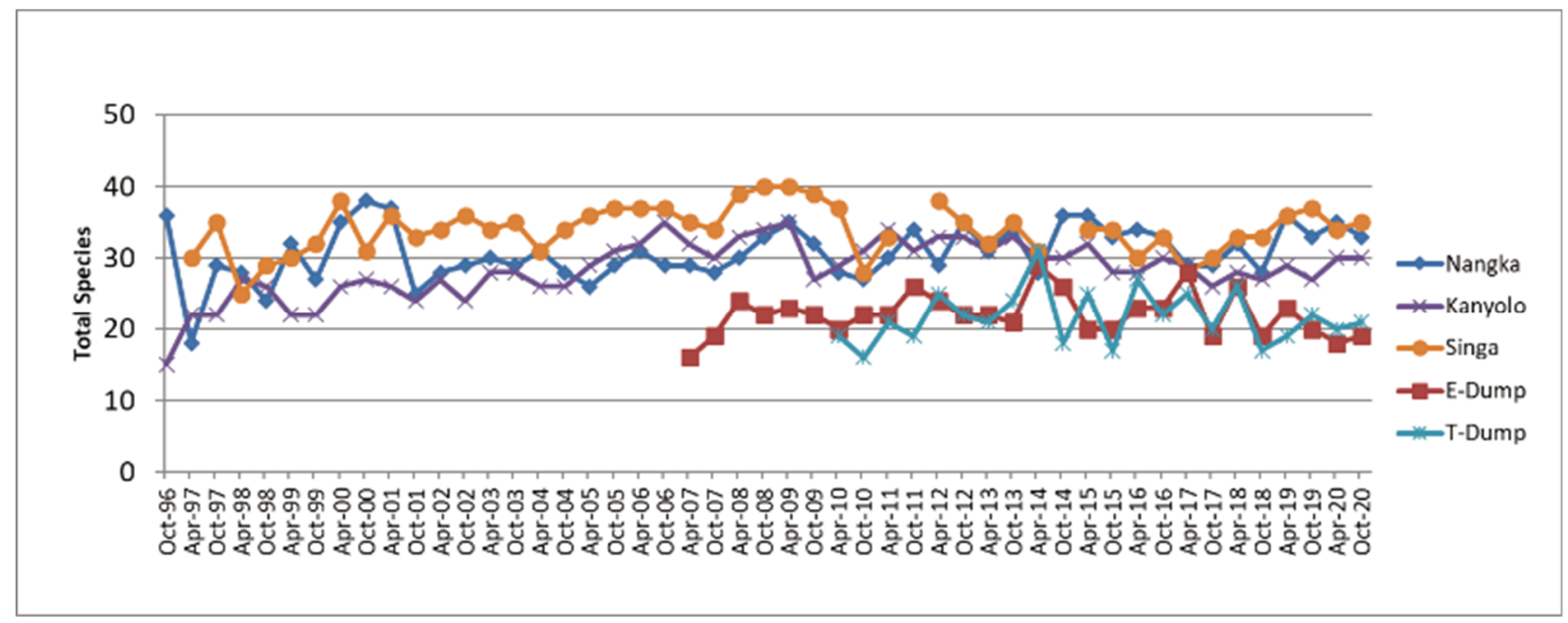

\section{Figure 13 Total bird species from census method in Batu Hijau}

Monitoring results for bats also show a similar trend to the birds. During monitoring in five primary locations on the nights of April and October 2020, the total number of bats caught and released were 503 individuals of 8 species with an overall density of $0.146 \mathrm{ind} / \mathrm{m}^{2}$ and $0.359 \mathrm{ind} / \mathrm{m}^{2}$ respectively. The density of bats in the reclamation area is still lower than that of natural forests (Figure 14).

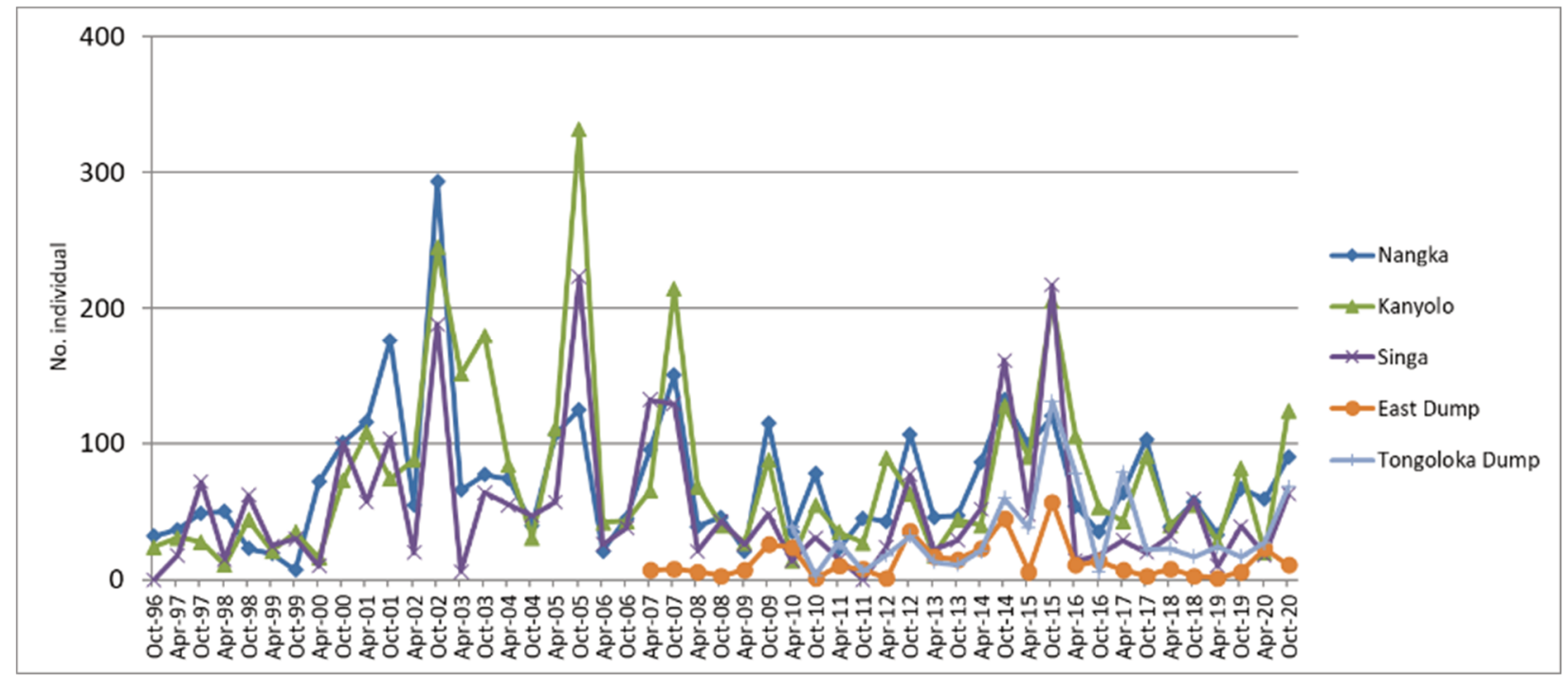

Figure 14 Number of Bats Captured in Batu Hijau

\section{Conclusion}

The reclamation program at Batu Hijau has been initiated since the beginning of the exploration phase that includes baseline study, laboratory and nursery scale experiment, and full-scale trial. The results obtained from these studies are then used as a technical guideline in concurrent reclamation activities.

Monitoring results show that long-term geotechnical slope stability, habitat restoration, and progressive ecological succession process are maintained. This proves that the goals of reclamation in Batu Hijau is achievable. 


\section{Acknowledgment}

The authors would like to thank PT Amman Minera Nusa Tenggara for the permission to publish this work, and to the dedicated mine rehabilitation personnel at Batu Hijau.

\section{References}

PT Amman Mineral Nusa Tenggara 2021, Environmental Management and Monitoring Implementation Report Second Semester, JulyDecember 2020.

Golder Associates Inc 1999, Waste Dump Management Plan Batu Hjau Project Volume 6 Tech Memo 6.1 thru Tech Memo 6.4. Unpublished consultant report submitted to PT Newmont Nusa Tenggara.

Golder Associates Ltd. And PPES Works (SARAWAK) Sdn Bhd 2004, Report on Geotechnical and Bioengineering Studies New 2:1 Test Slopes for Waste Dumps Batu Hijau Mine Sumbawa, Indonesia. Unpublished consultant's report submitted to PT Newmont Nusa Tenggara

Golder Associates Ltd. And PPES Works Sdn Bhd 2005, Report on Addendum to Geotechnical and Bioengineering Studies New 2:1 Test Slopes for Waste Dumps Batu Hijau Mine Sumbawa, Indonesia. Unpublished consultant's report submitted to PT Newmont Nusa Tenggara

Golder Associates 2013, Geotechnical Review Waste Dump Reclamation Slopes, Batu Hijau Mine, Sumbawa Indonesia. Unpublished consultant's report submitted to PT Newmont Nusa Tenggara

Juncosa, A and Hanes, T 2014, Batu Hijau Reclamation review. An unpublished consultant report prepared by Ecosynthesis Scientific \& Regulatory Services, Inc and Hydro Science and submitted to PT Newmont Nusa Tenggara

Pusat Studi Reklamasi Tambang IPB 2017, Pemantauan Lingkungan Komponen Iklim Mikro di Areal Reklamasi Batu Hijau PT Amman Mineral Nusa Tenggara, Nusa Tenggara Barat. Unpublished consultant report submitted to PT Amman Mineral Nusa Tenggara. Pusat Studi Reklamasi Tambang IPB 2017, Pemantauan Lingkungan Komponen Flora di Areal Reklamasi Batu Hijau PT Amman Mineral Nusa Tenggara, Nusa Tenggara Barat. Unpublished consultant report submitted to PT Amman Mineral Nusa Tenggara. 